\title{
Genetic variation of an endangered Malagasy frog, Mantella cowani, and its phylogeographic relationship to the widespread $M$. baroni
}

\author{
Ylenia Chiari ${ }^{1}$, Franco Andreone ${ }^{2}$, Miguel Vences ${ }^{3} \&$ Axel Meyer ${ }^{1, *}$ \\ ${ }^{1}$ Lehrstuhl für Zoologie und Evolutionsbiologie, Department of Biology, University of Konstanz, 78457, \\ Konstanz, Germany; ${ }^{2}$ Museo Regionale di Scienze Naturali, Sezione di Zoologia, 10123, Torino, Italy; \\ ${ }^{3}$ Zoological Institute, Technical University of Braunschweig, Spielmannstr. 8, 38106, Braunschweig, Germany \\ (*Corresponding author: Phone: +49-7531884163; Fax: +49-7531883018; E-mail: Axel.Meyer@uni-kon- \\ stanz.de)
}

Received 4 January 2005; accepted 10 February 2005

Key words: Amphibia, Mantella baroni, Mantella cowani, cytochrome b, hybridization

\begin{abstract}
We investigated the degree and distribution of the genetic variation, and phylogeography, of two species of Malagasy poison frogs, Mantella cowani and M. baroni. The former is critically endangered due to its restricted distribution, habitat destruction and overcollection for the pet trade. Analysis of $526 \mathrm{bp}$ of mtDNA (cytochrome $b$ ) resulted in separate haplotype networks for the two species, and discovered hybridization at a single locality. The two networks confirm the status of $M$. baroni and $M$. cowani as separate evolutionary species and units for conservation. Within both mitochondrial haplotype networks, specimens from different localities shared numerous identical haplotypes, even those from the most distant sample sites of $M$. baroni. Most populations were characterized by high haplotype diversity and no haplotype clades exclusive to geographical regions were observed. Protection of a few large populations of these species is therefore likely to conserve much of the mtDNA genetic diversity found in the entire species. While $M$. baroni is widespread and occurs in many nature reserves, we recommend efficient legal protection of some M. cowani habitats to protect this species against extinction.
\end{abstract}

\section{Introduction}

Amphibian populations are suffering worldwide declines, range contractions and extinctions (Stuart et al. 2004). This is due to different causes like habitat disturbance, diseases and pathogens, introduction of invasive species and exploitation for the pet-trade (reviewed e.g., in Semlitsch 2003). On Madagascar, the fourth largest islands of the world, over $99 \%$ of the amphibians are endemic. Amphibians are only represented on Madagascar by anurans with a number of species that surpasses 210 (Andreone and Luiselli 2003). Habitat destruction such as deforestation with the practice of slash-and-burn agriculture and heavy anthro- pogenic pressure negatively affects their survivorship and distribution (Raxworthy and Nussbaum 2000; Vallan 2000, 2002). In contrast, global declines caused by pathogens, especially chytrid fungi (Berger et al. 1998; Bosch et al. 2001; Carey et al. 2003) are so far apparently absent from Madagascar (Andreone et al. 2005). Mantella cowani is an endemic diurnal poison frog, which occurs mainly on the high plateau of east-central Madagascar. This species is confined to a small area of these highlands where primary forest has been almost completely destroyed or degraded (Vences et al. 1999; Andreone and Randrianirina 2003; Andreone et al. 2005). M. cowani is listed in the IUCN red list as critically endangered and in

Konstanzer Online-Publikations-System (KOPS)

URL: http://www.ub.uni-konstanz.de/kops/volltexte/2007/3398/

URN: http://nbn-resolving.de/urn:nbn:de:bsz:352-opus-33987 
CITES Appendix II for the decline of its habitat, drastic population reduction and the fragmented distribution (Andreone et al. 2005). This species is also over-exploited for the international pet-trade due to its conspicuous and attractive bright colouration. Little is known about its natural history, capacity for long-term survival in degraded habitats, and the status of most of its populations.

In the genus Mantella, five major groups can be genetically distinguished (Schaefer et al. 2002; Chiari et al. 2004; Vences et al. 2004). M. cowani belongs to the $M$. cowani group that also includes $M$. baroni, $M$. haraldmeieri and M. nigricans. The taxonomic history of these species has been complex (reviewed by Vences et al. 1999) and M. cowani and M. baroni may be sister species (Vences et al. 2004). M. baroni is known from a relatively wide distribution area in the central eastern mid-altitude rainforests, at elevations up to about $1000 \mathrm{~m}$ above sea level, whereas $M$. cowani is present only in the highland areas west of the rainforest belt and has been recorded up to $2000 \mathrm{~m}$ altitude at Ambatodradama (Vences et al. 1999). Probable hybrids between these two species have been identified in the pet trade, but the geographic origin of these individuals remained unknown (Glaw and Vences 2000).

Here we comparatively investigate the phylogeography and genetic variation of $M$. cowani and $M$. baroni by examining variation in $526 \mathrm{bp}$ of the mitochondrial cytochrome $b$ gene and discuss our results in regard to potential future conservation efforts.

\section{Materials and methods}

\section{Sampling}

Fieldwork was carried out in February 2002 and 2003. Eleven populations (eight of M. baroni and three of $M$. cowani) were sampled and geographic coordinates and altitude above sea level recorded by GPS (Table 1). The sampling localities extend along a North-South transect of ca. $400 \mathrm{~km}$ in central eastern Madagascar (Figure 1), covering a large part of the distribution area of the two species. Sympatry of the two species was recorded at one locality (Farimazava) (Figure 1). Frogs were classified morphologically either as $M$. cowani $(n=33), M$. baroni $(n=67)$, or "putative" hybrids $(n=6)$, based on their morphology when their colouration was intermediate. "Putative" hybrids had an orange-yellowish colouration, more extended lateral spots (versus small and rounded red spots in M. cowani), residuals of cephalic lines (clearly delineated in $M$. baroni and lacking in $M$. cowani) and presence of yellowish shading on tibiae (versus red bands in $M$. cowani and blackorange patterned tibiae in $M$. baroni). Tissue samples were collected by toe-clipping all encountered individuals, most of which were subsequently released. Representative voucher specimens were preserved in the collections of the Museo di Scienze Naturali di Torino, the Zoological Museum Amsterdam and the Zoologische Staatssammlung München.

Table 1. Coordinates, species and sample size for each locality

\begin{tabular}{llllll}
\hline Locality & $\begin{array}{l}\text { Locality } \\
\text { number }\end{array}$ & Coordinates & Altitude (m) & Species & Sample size \\
\hline Fierenana & 1 & $18^{\circ} 32^{\prime} 36^{\prime \prime} \mathrm{S}-48^{\circ} 26^{\prime} 56^{\prime \prime} \mathrm{E}$ & 948 & M. baroni & 1 \\
Andriabe & 2 & $18^{\circ} 36^{\prime} 46^{\prime \prime} \mathrm{S}-48^{\circ} 19^{\prime} 34^{\prime \prime} \mathrm{E}$ & 1047 & M. baroni & 5 \\
Vohidrazana & 3 & $18^{\circ} 57^{\prime} 57^{\prime \prime} \mathrm{S}-48^{\circ} 30^{\prime} 37^{\prime \prime} \mathrm{E}$ & 731 & M. baroni & 10 \\
Mantady & 4 & $18^{\circ} 49^{\prime} 48^{\prime \prime} \mathrm{S}-48^{\circ} 25^{\prime} 56^{\prime \prime} \mathrm{E}$ & 966 & M. baroni & 1 \\
Andranomena & 5 & $1^{\circ} 01^{\prime} 30^{\prime \prime} \mathrm{S}-48^{\circ} 10^{\prime} 0^{\prime \prime} \mathrm{E}$ & 921 & M. baroni & 2 \\
Tsinjoarivo region & 6 & No precise coordinates $^{\prime}-$ & M. baroni & 3 \\
Ranomafana & 7 & $21^{\circ} 13^{\prime} 34^{\prime \prime} \mathrm{S}-47^{\circ} 22^{\prime} 10^{\prime \prime} \mathrm{E}$ & 1152 & M. baroni & 13 \\
Farimazava & 8 & $20^{\circ} 50^{\prime} 06^{\prime \prime} \mathrm{S}-47^{\circ} 19^{\prime} 95^{\prime \prime} \mathrm{E}$ & $1380-1420$ & M. cowani-M. baroni & 8 M. cowani-33 \\
& & & & & M. baroni \\
Soamazaka & 9 & $20^{\circ} 45^{\prime} 22^{\prime \prime} \mathrm{S}-47^{\circ} 17^{\prime} 38^{\prime \prime} \mathrm{E}$ & $1600-1650$ & M. cowani & 4 \\
Vohisokina & 10 & $20^{\circ} 42^{\prime} 18^{\prime \prime} \mathrm{S}-47^{\circ} 17^{\prime} 14^{\prime \prime} \mathrm{E}$ & $1580-1620$ & M. cowani & 20 \\
Vatolampy & 11 & $20^{\circ} 49^{\prime} 40^{\prime \prime} \mathrm{S}-47^{\circ} 19^{\prime} 08^{\prime \prime} \mathrm{E}$ & $1540-1580$ & M. cowani & 6 \\
\hline
\end{tabular}

Locality numbers refer to those in Figure 1.

${ }^{a}$ The coordinates from Ranomafana refer to a bridge near Vohiparara where most samples were collected; some samples from other sites within Ranomafana National Park were pooled with these for analysis. 


\section{Laboratory techniques}

Total genomic DNA was extracted from toeclips preserved in $99 \%$ ethanol using a proteinase $\mathrm{K}$ digestion (final concentration $1 \mathrm{mg} / \mathrm{ml}$ ). DNA was isolated by a standard salt extraction protocol (Bruford et al. 1992).

Fragments of $526 \mathrm{bp}$ of cytochrome $b$ were amplified via the polymerase chain reaction (PCR) using the primers Cytb-c and CBJ10933 from Bossuyt and Milinkovitch (2000). To amplify the cytochrome $b$ fragment, PCRs were performed in $25 \mu$ reactions containing 1.0 unit of REDTaq DNA Polymerase (Sigma, Taufkirchen, Germany), $50 \mathrm{ng}$ genomic DNA, $10 \mathrm{nmol}$ of each primer, $15 \mathrm{nmol}$ of each dNTP, $50 \mathrm{nmol}$ additional $\mathrm{MgCl}_{2}$ and the REDTaq PCR reaction buffer $(10 \mathrm{mM}$ Tris- $\mathrm{HCl}, \mathrm{pH} 8.3,50 \mathrm{mM} \mathrm{KCl}, 1.1 \mathrm{mM} \mathrm{MgCl} 2$ and $0.01 \%$ gelatine) using the following conditions: an initial denaturation at $94{ }^{\circ} \mathrm{C}$ for $1: 30 \mathrm{~min}$; 35 cycles at $94{ }^{\circ} \mathrm{C}$ for $30 \mathrm{~s}$, annealing temperature of $53{ }^{\circ} \mathrm{C}$ for $45 \mathrm{~s}$, extension at $72{ }^{\circ} \mathrm{C}$ for $1: 30 \mathrm{~min}$; final extension of 10:00 min at $72{ }^{\circ} \mathrm{C}$.

PCR products were checked on $1 \%$ agarose gels and purified using QIAquick spin columns (Qiagen) prior to cycle sequencing. Sequence data collection and visualisation were performed on an ABI 3100 automated sequencer. Sequencing reactions were prepared according to the manufacturers instructions, using $\mathrm{ABI}$ sequence mix (BigDye ${ }^{\circledR}$ Terminator V3.1 Sequencing Standard, Applied Biosystems).

We obtained cytochrome $b$ sequences of 1-41 specimens from each population of the two species (see Table 1). Sequences were deposited in GenBank; accession numbers: AY862201-AY862306.

\section{Phylogeography and population genetics}

Unambiguous alignment of the sequences was possible by eye, as they contained no indels. Sequences were verified and aligned with Sequence Navigator (Applied Biosystems) software. Different haplotypes were identified by Collapse v 1.1 (Posada 1999).

A minimum-spanning network was constructed using the TCS software package (Clement et al. 2000), which employs the method of Templeton et al. (1992). It calculates the number of mutational steps by which pairwise haplotypes differ and computes the probability of parsimony (Templeton et al. 1992) for pairwise differences until the prob- ability exceeds 0.95 . In addition, we performed a maximum likelihood phylogenetic analysis of all identified haplotypes. The topology inferred using this method was then used to choose among unresolved connections in the haplotype network (Figure 2). Maximum likelihood (ML) analyses were carried out using PAUP* (Swofford 2002), using the heuristic search option with tree-bisection-reconnection (TBR) branch swapping and 10 random addition sequence replicates, following substitution model parameter estimation with hierarchical likelihood ratio tests as implemented in Modeltest version 3.06 (Posada and Crandall 1998).

\section{Results}

We obtained 526 bp of cytochrome $b$ sequences of 106 individuals from 11 populations of $M$. baroni and $M$. cowani. These contained 57 different haplotypes, of which 47 were unique. The TCS analysis produced two main haplotype networks (Figure 2). Haplotype sharing was restricted to putative and "a posteriori" hybrids at the locality Farimazava (Figure 1). We defined "a posteriori" hybrids as those individuals that were morphologically identified as $M$. baroni but contained a haplotype of $M$. cowani. The first network contains sequences of $36 \mathrm{M}$. cowani individuals from four populations (Soamazaka, Vohisokina, Farimazava and Vatolampy) (Figure 1) and four " $a$ posteriori" hybrids from Farimazava, grouped in 14 haplotypes. The most abundant haplotype is in the central position and consists of a group of 16 individuals of $M$. cowani in which all the sampling localities are represented and two of the four hybrids. The second haplotype network contains sequences of $64 \mathrm{M}$. baroni individuals from eight populations (Mantady, Vohidrazana, Andranomena, Ranomafana, Tsinjoarivo region, Fierenana, Andriabe, Farimazava) and two "putative" hybrids grouped in 43 haplotypes. The most abundant haplotype is in the central position and was found in 14 individuals from five localities (Andriabe, Tsinjoarivo region, Ranomafana, Farimazava, Vohidrazana). From 18 to 25 pairwise substitutions are necessary to connect the two separate networks. However, we inferred high levels of gene flow within the two species, in particular for M. baroni, which contained 36 different haplotypes in our entire sample. In this species, the 


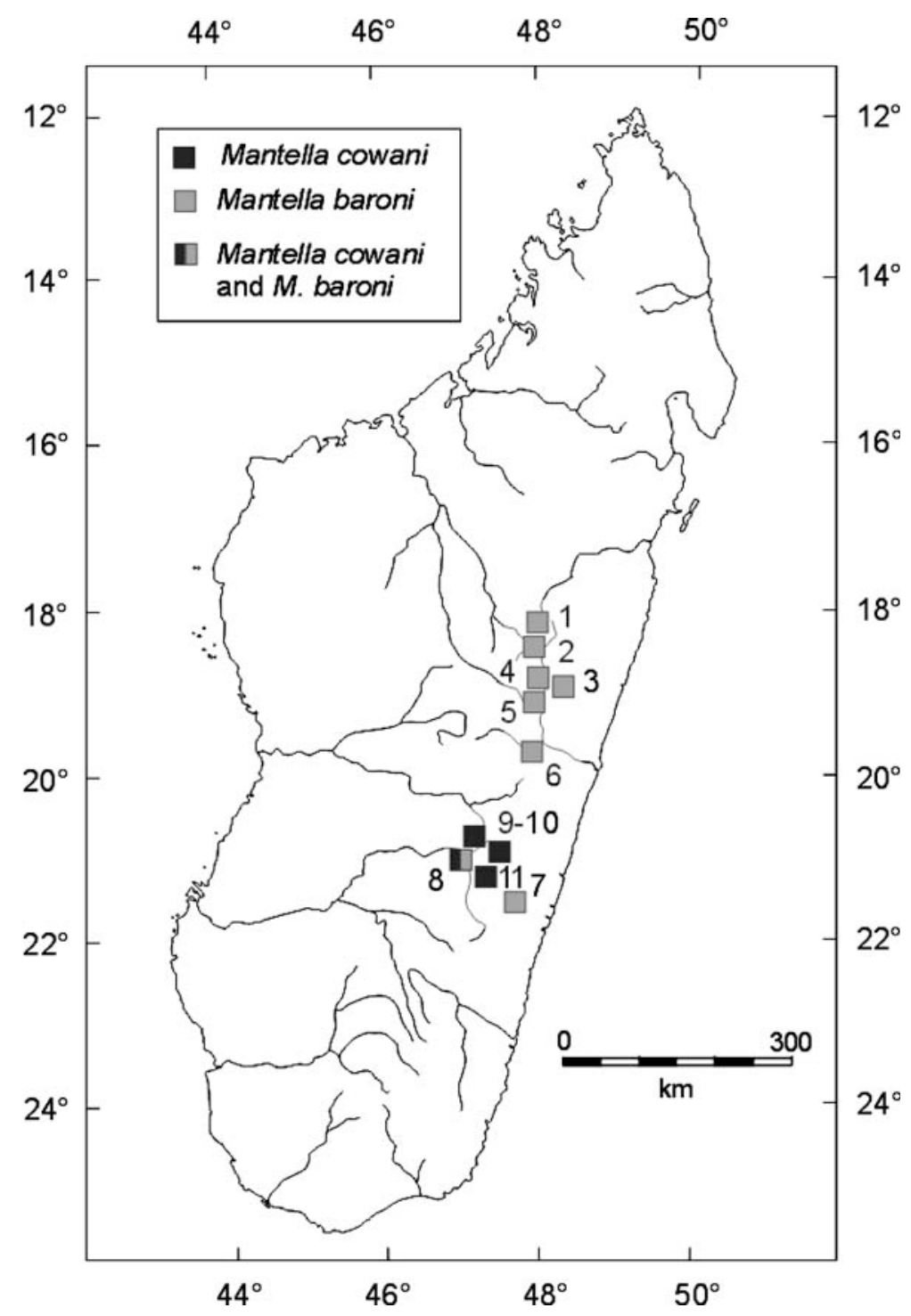

Figure 1. Map of sampled localities of Mantella cowani and M. baroni. Localities are coded as in Table 1.

most common haplotype was found in individuals from many populations, including the relatively most distant northern and southern ones.

\section{Discussion}

Defining a species has become a particularly important issue in conservation biology efforts (Moritz 1994). Hybridization phenomena make species definition more complex but do not invalidate them. Hybridization is widely known in amphibians (e.g., Szymura 1993; Vines et al.
2003). In the genus Mantella hybridization among different species has been recorded in captivity (Glaw et al. 2000). Haplotype sharing among taxa has also been observed recently (Chiari et al. 2004; Vences et al. 2004).

Mantella cowani differs by a number of morphological features from M. baroni. It is larger, has shorter hind limbs, less expanded toe-tips, smaller relative tympanum and eye diameters. $M$. cowani is also coloured differently, being characterized by a black body colouration with small red-orange flank blotches and red-orange bands on the hind limbs vs. large yellow-green flank blotches and 
(a)

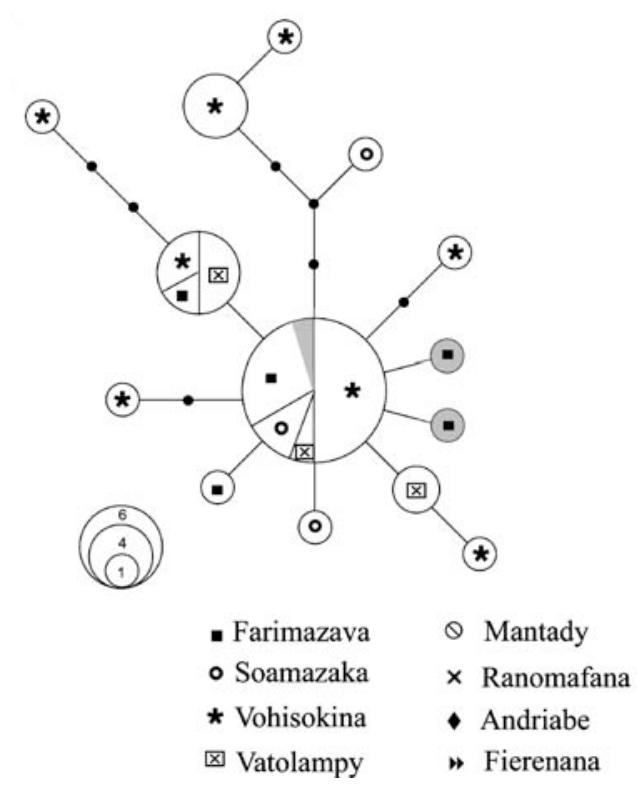

(b)

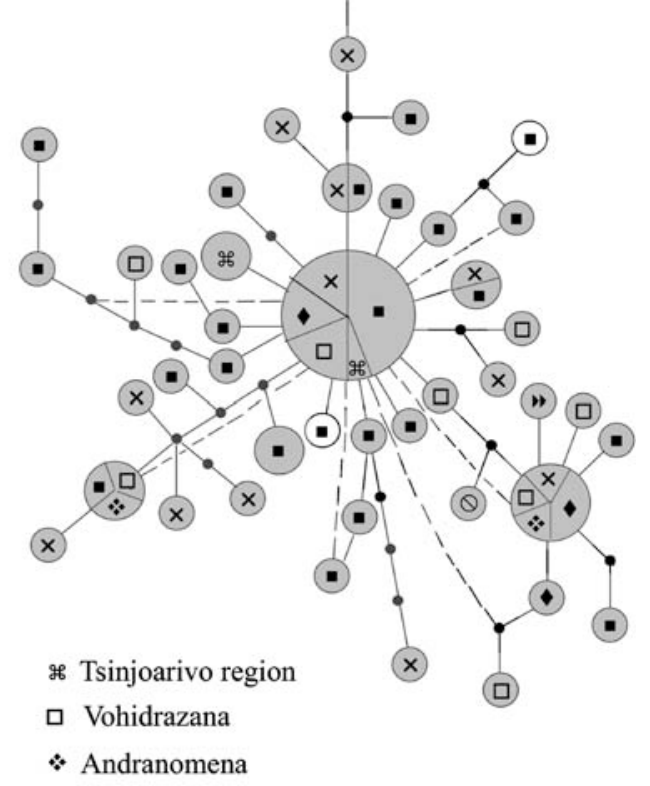

Figure 2. Haplotype networks of populations assigned to Mantella cowani (white; mainly in network A) and Mantella baroni (grey; mainly in network B). Network A contains four specimens (symbolized by grey colour) that were identified as $M$. baroni and not morphologically recognized as hybrids ("a posteriori" hybrids). Network B contains two specimens (white circles) that had been morphologically identified as possible hybrids ("putative" hybrids). Three other such putative hybrids are clustering within network A (not marked). All hybrids are from the single locality in which both species were found in syntopy (Farimazava). The dashed lines indicate links in the haplotype network with a lower level of ML support than the solid lines. Different sized circles indicate different haplotype counts, as indicated in the lower left corner.

orange-black patterning of hind limbs of $M$. baroni (Glaw and Vences 2000). M. baroni also has supraocular stripes, which are absent in M. cowani. Because the two species have similar advertisement calls consisting of series of click notes (Glaw and Vences 1994) they probably lack an efficient mechanism of prezygotic isolation. At Farimazava, we found hybrids in both of the haplotype networks. This result is referred only from mtDNA data (cytochrome $b$ ). The number of "putative" hybrids was actually larger than that detected with our analysis ("a posteriori" hybrids): of the total of eight individuals of $M$. cowani collected in Farimazava, five were recognized as "putative" hybrids. The reduced number of detected hybrids in our analysis compared to these morphological observations might be due to the use of a maternally inherited marker, mtDNA. The use of nuclear markers such as microsatellites would enable us to confirm the introgression since our data cannot exclude that the system represents a phylogeographic pattern of category II as de- fined by Avise (2000). In this scenario, some anciently separated lineages within a species might by chance have been retained whereas many intermediate genotypes were lost over time by gradual lineage sorting.

However, based on the relatively large number of steps (at least 18) separating the two haplotype networks in Figure 2 we here confirm the genetic differentiation between $M$. cowani and $M$. baroni. Together with the apparent ecological differences as reflected by different altitudinal occurrence, the available data support a status of $M$. cowani and $M$. baroni as separate species under the evolutionary species concept (Frost and Hillis 1990) and as separate entities for conservation. Within these, most populations are genetically diverse, containing many different haplotypes. This indicates that, for $M$. cowani and M. baroni, an intensive effort to protect a few populations would be sufficient to conserve much of their mitochondrial DNA genetic diversity. While $M$. baroni occurs in many nature reserves (Vences et al. 1999), no single occurrence 
of $M$. cowani in a protected area is known to date. We therefore propose the inclusion into Madagascar's network of reserves of some parcels of the remaining high plateau habitat of $M$. cowani.

\section{Acknowledgements}

We are indebted to Matthias Sanetra and Arie van der Meijden for valuable comments on the manuscript and to Walter Salzburger for help with the graphics. We are grateful to the University of Antananarivo and ICTE/MICET for logistic assistance and to the Malagasy authorities for research and export permits. Y. Chiari was supported by a grant of the Landesgraduiertenförderung Baden-Württemberg. F. Andreone was supported by grants from Nando Peretti Foundation, DAPTF/IUCN and National Amphibian Conservation Center. Laboratory and field work received support from grants of the Deutsche Forschungsgemeinschaft to $M$. Vences and A. Meyer, and by the BIOPAT foundation to M. Vences.

\section{References}

Andreone F, Cadle JE, Cox N, Glaw F, Nussbaum RA, Raxworthy CJ, Stuart S, Vallan D, Vences M (2005) Species review of amphibian extinction risks in Madagascar: Conclusions from the global amphibian assessment. Conserv. Biol, 19, 1790-1802.

Andreone F, Luiselli LM (2003) Conservation priorities and potential threats influencing the hyper-diverse amphibians of Madagascar. Ital. J. Zool., 70, 53-63.

Andreone F, Randrianirina JE (2003) It's not carnival for the harlequin mantella! Urgent actions needed to conserve Mantella cowani, an endangered frog from the high plateau of Madagascar. Froglog, 59, 1-2.

Avise JC (2000) Phylogeography: The History and the Formation of Species. Harvard University Press, Cambridge, London, UK.

Berger L, Speare R, Daszak P, Green DE, Cunningham AA, Goggin CL, Slocombe R, Ragan M, Hyatt AD, McDonald KR, Hines HB, Lips KR, Marantelli G, Parkes H (1998) Chytridiomycosis causes amphibian mortality associated with population declines in the rain forests of Australia and Central America. Proc. Natl. Acad. Sci. USA, 95, 9031-9036.

Bosch J, Martinez-Solano I, Garcia-Paris M (2001) Evidence of a chytrid fungus infection involved in the decline of the common midwife toad (Alytes obstetricans) in protected areas of central Spain. Biol. Conserv., 97, 331-337.
Bossuyt F, Milinkovitch MC (2000) Convergent adaptive radiations in Madagascan and Asian ranid frogs reveal covariation between larval and adult traits. Proc. Natl. Acad. Sci. USA, 97, 6585-6590.

Bruford MW, Hanotte O, Brookfield JFY, Burke T (1992) Single-locus and multilocus DNA fingerprint. In: Molecular Genetic Analysis of Populations: A Practical Approach (ed. Hoelzel AR), pp. 225-270. IRL Press, Oxford.

Carey C, Pessier A, Peace A (2003) Pathogens, infectious disease, and immune defenses. In: Amphibian Conservation (ed. Semlitsch RD), pp. 127-136. Smithsonian Book, Washington and London.

Chiari Y, Vences M, Vieites DR, Rabemananjara F, Bora P, Ramilijaona Ravoahangimalala O, Meyer A (2004) New evidence for parallel evolution of colour patterns in Malagasy poison frogs (Mantella). Mol. Ecol., 13, 3763-3774.

Clement X, Posada D, Crandall K (2000) TCS: a computer program to estimate gene genealogies. Mol. Ecol., 9, 1657-1659.

Frost DR, Hillis DM (1990) Species in concept and practice: herpetological applications. Herpetologica, 46, 87-104.

Glaw F, Vences M (1994) A Fieldguide to the Amphibians and Reptiles of Madagascar, 2nd edn. Vences and Glaw, Köln.

Glaw F, Vences M (2000) Madagaskar-Giftfrösche: Färbungsvariation zwischen Mantella cowani und M. baroni. D. Aquar.-Terr. Z., 53, 48-50.

Glaw F, Vences M, Schmidt K (2000) Nachzucht, Juvenilfärbung und Oophagie von Mantella laevigata im Vergleich zu anderen Arten der Gattung (Amphibia: Ranidae). Salamandra, 36, 1-24.

Moritz C (1994) Application of mitochondrial DNA analysis in conservation: critical review. Mol. Ecol., 3, 401-411.

Posada D (1999) Collapse, Version 1.1, Department of Zoology, Brigham Young University, Salt Lake City, UT.

Posada D, Crandall KA (1998) Modeltest: testing the model of DNA substitution. Bioinformatics, 14, 817-818.

Raxworthy CJ, Nussbaum RA (2000) Extinction and extinction vulnerability of amphibians and reptiles in Madagascar. Amph. Rept. Cons., 2, 15-23.

Schaefer HC, Vences M, Veith M (2002) Molecular phylogeny of Malagasy poison frogs, genus Mantella (Anura: Mantellidae): homoplastic evolution of color pattern in aposematic amphibians. Org. Div. Evol., 2, 97-105.

Semlitsch RD (2003) Amphibian Conservation, Smithsonian Books, Washington and London.

Stuart SN, Chanson JS, Cox NA, Young BE, Rodrigues ASL, Fischman DL, Waller RW (2004) Status and trends of amphibian declines and extinctions worldwide. Science, 306, $1783-1786$.

Swofford DL (2002) PAUP* Phylogenetic Analysis using Parsimony (* and other methods), Version 4.ob10. Sinauer Associates, Sunderland, MA.

Szymura JM (1993) Analysis of hybrid zones with Bombina. In: Hybrid Zones and the Evolutionary Process (ed. Harrison R.), pp. 261-289. Oxford University Press, New York.

Templeton AR, Crandall KA, Sing CF (1992) A cladistic analysis of phenotypic associations with haplotypes inferred from restriction endonuclease mapping and DNA sequence data. III. Cladogram estimation. Genetics, 132, 619-633.

Vallan D (2000) Influence of forest fragmentation on amphibian diversity in the nature reserve of Ambohitantely, highland Madagascar. Biol. Conserv., 96, 31-43. 
Vallan D (2002) Effects of anthropogenic environmental changes on amphibian diversity in the rainforest of eastern Madagascar. J. Tropical Ecol., 18, 725-742.

Vences M, Chiari Y, Raharivololoniaina L, Meyer A (2004) High mitochondrial diversity within and among populations of Malagasy poison frogs. Mol. Phylogenet. Evol., 30, 295-307.

Vences M, Glaw F, Böhme W (1999) A review of the genus Mantella (Anura, Ranidae, Mantellinae): taxonomy, distri- bution and conservation of Malagasy poison frogs. Alytes, 17, 3-72.

Vines TH, Koehler SC, Thiel M, Ghira I, Sands TR, MacCallum CJ, Barton NH, Nuernberger B (2003) The maintenance of reproductive isolation in a mosaic hybrid zone between the fire-bellied toads Bombina bombina and B. variegata. Evolution, 57, 1876-1888. 